ISSN 1979-5572 (print) | ISSN 2541-6480 (online)

http://ejurnal.iainpare.ac.id/index.php/kuriositas

\title{
KURIOSITAS
}

Media Komunikasi Sosial dan Keagamaan

\begin{tabular}{lll}
\hline Volume 14 & No.1, Juni 2021 & Halaman 1-18
\end{tabular}

\section{The Social Construction of Yasinan in the Form of Social Identity "a Case Study in Ketapangkuning Village, Ngusikan Subdisctrict, Jombang Regency"}

\author{
Widia Dwi Rahmawati ${ }^{1}$, Agus Mahfudz Fauzi ${ }^{2}$ \\ 1,2 Universitas Negeri Surabaya \\ widiadwirahmawati31@gmail.com, agusmfauzi@unesa.ac.id
}

\begin{abstract}
Tradition becomes an important part that is closely related to people's lives. The existence of tradition is often motivated by many things, one of which is religion. In Javanese society, the religious element enters almost all traditions carried out. Yasinan tradition is a manifestation of the melting of Islamic religious values in society. Until now Yasinan Tradition still continues to undergo the regeneration process. However, as the era of this tradition has grown, the value shift is due to social construction. This condition also occurs in yasinan tradition carried out by the people of Ketapangkuning Village. Currently, Yasinan Tradition is only used as a medium for obtaining wealth alone. Thus, in its implementation has indirectly formed a social identity of a particular group. The purpose of this research is to see how the construction of Yasinan Tradition in the formation of social identity of local villagers. This research is included in qualitative research type. The method used in this study is social construction. The results showed that there is a shift in value in yasinan tradition conducted by the people of Ketapangkuning Village. Yasinan tradition becomes a medium in shaping the social identity of the local community. The formation of social identity is demonstrated through the 'arisan' activities carried out in the tradition.
\end{abstract}

Keywords: Social Construction; Yasinan; and Social Identity. 


\begin{abstract}
ABSTRAK
Tradisi menjadi bagian penting yang erat kaitannya dengan kehidupan masyarakat. Keberadaan tradisi sering kali dilatarbelakangi oleh banyak hal, salah satunya yaitu agama. Pada masyarakat Jawa, unsur keagamaan memasuki hampir seluruh tradisi yang dijalankan. Tradisi Yasinan merupakan wujud meleburnya nilai-nilai agama Islam di masyarakat. Hingga sekarang Tradisi Yasinan masih terus mengalami proses regenerasi. Akan tetapi, seiring berkembangnya zaman tradisi ini mengalami pergeseran nilai akibat konstruksi sosial. Kondisi tersebut juga terjadi pada Tradisi Yasinan yang dilakukan oleh masyarakat Desa Ketapangkuning. Saat ini, Tradisi Yasinan hanya dijadikan sebagai media untuk memperoleh kekayaan semata. Sehingga, dalam pelaksanaannya secara tidak langsung telah membentuk suatu identitas sosial kelompok tertentu. Tujuan dari peneltian ini yaitu untuk melihat bagaimana konstruksi Tradisi Yasinan dalam pembentukan identitas sosial masyarakat desa setempat. Penelitian ini termasuk dalam jenis penelitian kualitatif. Metode yang digunakan dalam penelitian ini yaitu konstruksi sosial. Hasil penelitian menunjukkan bahwa terdapat pergeseran nilai dalam Tradisi Yasinan yang dilakukan oleh masyarakat Desa Ketapangkuning. Tradisi Yasinan menjadi media dalam membentuk identitas sosial masyarakat setempat. Pembentukan identitas sosial ditunjukkan melalui kegiatan 'arisan' yang dilakukan dalam tradisi tersebut.
\end{abstract}

Kata Kunci: Konstruksi Sosial; Yasinan; dan Identitas Sosial.

\title{
PENDAHULUAN
}

Agama menjadi bagian penting dalam hidup seseorang, tidak hanya sebagai pedoman hidup. Melainkan juga telah menyentuh berbagai aspek kehidupan lainnya, seperti sosial. Meleburnya agama dalam masyarakat menunjukkan bahwa agama bersifat dinamis yang dapat menyesuaikan dengan kondisi yang ada. Pada Masyarakat Jawa, proses akulturasi agama dalam masyarakat ditunjukkan dalam berbagai tradisi yang ada. Tradisi ialah pola perilaku atau kepercayaan yang telah menjadi bagian dari suatu budaya yang telah lama dikenal, hingga menjadi adat istiadat dan 
kepercayaan secara turun temurun. Dalam ilmu antropologi, tradisi lahir dari akal manusia yang dapat memperkirakan kondisi dirinya dan sekitar. Sehingga, dapat mengadakan pilihan dan seleksi dari berbagai alternatif yang ada untuk mencapai efektifitas yang optimal dalam mempertahankan hidupnya (Koentjaraningrat, 2009).

Tradisi menjadi salah satu media penyebaran Islam sejak awal masuk di Indonesia hingga saat ini. Hampir seluruh tradisi yang ada telah memuat nilai-nilai keagamaan di dalamnya. Hal ini juga ditunjukkan pada Tradisi Yasinan yaitu, amalan rutin membaca Surah Yasin dengan dilakukan secara bersama-sama. Kegiatan ini dilakukan setiap hari Kamis, setelah melaksanakan shalat Maghrib. Salah satu penelitian mengungkap bahwa, Pengajian Yasinan merupakan salah satu strategi peyebaran agama yang diamalkan oleh kelompok Nadhatul Ulama (NU) (Hayat, 2014). Maka dari itu, pelaksanaan Yasinan umumnya ditemukan di daerah pedesaan atau perkampungan yang masyarakatnya berasal dari kalangan NU. Meskipun demikian, pembacaan Yasin tidak hanya dilakukan oleh warga NU saja, tetapi juga dilakukan oleh berbagai lapisan masyarakat.

Pada pelaksanaannya, setiap masyarakat memiliki cara masingmasing dalam menjalankan Tradisi Yasinan ini. Misalnya dalam penelitian yang dilakukan oleh Ahmad Zainuddin dan Faiqotul Hikmah menunjukkan, bahwa Tradisi Yasinan yang dilakukan di Pondok Pesantren Ngalah Pasuruan memiliki cara yang berbeda. Prosesi Yasinan dilakukan dengan memposisikan para santri untuk duduk melingkar yang di tengahtengahnya telah disediakan baskom berisi air. Setelah selesai membaca yasin, air tersebut kemudian ditiup atas arahan dari pengasuh Ponpes. Pelaksanaan Yasinan dalam hal ini bertujuan sebagai pegangan 
(keistiqomahan), selain itu juga sebagai media suwuk (obat) (Zainuddin \& Hikmah, 2019).

Pola pelaksanaan yang berbeda juga terjadi di Pondok Pesantren Kedung Kenong Madiun. Hasil penelitian yang dilakukan Agus Roiawan menunjukkan bahwa, terdapat perbedaan pelaksanaan Yasinan di Ponpes tersebut dengan Ponpes lainnya. Hal ini ditunjukkan dengan pembacaan ayat tertentu secara berulang-ulang yakni, pada ayat ke-9 dibaca sebanyak 113 kali dan ayat ke-58 dibaca sebanyak 40 kali. Pelaksanaan tradisi ini juga melahirkan tiga makna. Pertama, makna objektif yang menempatkan Tradisi Yasinan sebagai suatu kewajiban. Kedua, makna ekspresif bahwa tradisi Yasinan merupakan saran untuk meningkatkan kualitas diri kepada Allah SWT. Ketiga, makna dokumenter sebagai makna tersirat dari pelaksanaan tradisi ini. Dengan menjadikan Tradisi Yasinan sebagai suatu kebiasaan maka dengan sendirinya akan melekat pada diri para santri (Roiawan, 2019).

Secara umum, Tradisi Yasinan tidak bertentangan dengan nilai-nilai Islam. Sehingga, tradisi ini tetap berjalan dari generasi ke generasi. Surah Yasin merupakan bagian dari Al-Qur'an dan membacanya merupakan kewajiban bagi setiap muslim (Sumarni, 2018). Dengan demikian, maka tradisi Yasinan memiliki dua fungsi utama, yaitu sebagai hablu minallah dan hablu minannas (Muniri, 2020). Tradisi ini juga masih berlangsung di masyarakat Desa Ketapangkuning, dilakukan setiap hari Kamis setelah sholat Maghrib. Dalam pelaksanaannya juga hampir sama dengan Tradisi Yasinan pada umumnya, seperti membaca Surah Yasin, sholawat, dan juga do'a. Akan tetapi, terdapat hal berbeda dalam tradisi Yasinan yang dilakukan oleh ibu-ibu di Desa Ketapangkuning. Tradisi Yasinan selain dijadikan sebagai momentum untuk mengirim do'a kepada leluhur, juga 
dijadikan sebagai media untuk menabung. Konsep menabung yang diterapkan dalam kegiatan Yasinan mengambil konsep dari kegiatan Arisan.

Realitas tersebut ditunjukkan dengan adanya sistem arisan dalam pelaksanaan tradisi yasinan. Setiap anggota yasinan dapat memberikan sejumlah uang kepada anggota lainnya secara bergilir. Pada setiap akhir acara akan dilakukan pengundian, nama anggota yang keluar pada saat itu akan memperoleh uang yang telah ditabungnya juga uang dari anggota lainnya. Dalam proses menabung tersebut, secara tidak langsung telah membentuk suatu identitas sosial yang didasarkan pada besaran uang yang ditabungkan. Fenomena tersebut menjadi cukup menarik untuk dikaji, di mana telah terjadi pergeseran makna tradisi yasinan yang dilakukan oleh ibu-ibu di Desa Ketapangkuning.

Penelitian ini termasuk ke dalam jenis pendekatan kualitatif yang menekankan pada pemaparan temuan secara naratif.Teknik pengumpulan data dilakukan secara langsung melalui kegiatan observasi atau pengamatan dan juga wawancara kepada subjek penelitian. Subjek dalam penelitian ini dipilih dengan menggunakan teknik purposive random sampling atau pengambilan sampel berdasarkan tujuan.Teknik ini digunakan dalam melihat proses konstruksi sosial tentang Yasinan dilakukan di masyarakat. Karakteristik subjek yang dipilih yaitu, subjek merupakan anak dan ibu dan menjadi anggota aktif Yasinan di Desa Ketapangkuning, Ngusikan, Jombang. Jumlah informan yang diambil dalam penelitian ini yaitu, sebanyak 10 orang yang memiliki hubungan keluarga. Hal ini ditujukan dalam melihat proses internalisasi terkait dengan Tradisi Yasinan, terutama pada praktik arisan di dalamnya. Waktu dalam penelitian ini dilakukan selama bulan Januari sampai bulan Februari. 
Data yang telah diperoleh di lapangan berupa data primer dan data sekunder. Data primer berasal dari kegiatan observasi di lapangan dan kegiatan wawancara kepada sejumlah informan. Sedangkan, data sekunder berasal dari dokumen serta kajian literatur yang mendukung.Tahap selanjutnya, data yang diperoleh tersebut akan dilakukan analisis. Teknik analisis data yang digunakan yaitu Model Miles dan Huberman, yang meliputi tiga tahap(Sugiyono, 2012). Tahap pertama reduksi data, berarti merangkum, memilih hal-hal pokok, dan memfokuskan pada hal-hal yang penting yang selanjutnya dicari tema dan polanya. Selanjutnya, pada tahap kedua yaitu penyajian data. Penyajian ini dapat dilakukan dalam bentuk uraian singkat. Proses penyajian data dapat memudahkan untuk memahami apa yang terjadi, dan merencanakan kerja selanjutnya berdasarkan apa yang dipahami tersebut. Terakhir, tahap penarikan kesimpulan dan verifikasi. Kesimpulan dalam penelitian kualitatif merupakan temuan baru yang sebelumnya belum pernah ada.

\section{HASIL DAN PEMBAHASAN}

\section{Tradisi Yasinan dan Praktik 'Arisan Islami'}

Masa pandemi telah menimbulkan berbagai keterbatasan dalam aktivitas masyarakat sehari-hari. Saat ini, seluruh masyarakat telah dihimbau untuk mematuhi protokol kesehatan yang ada. Upaya tersebut juga dilakukan oleh pemerintah tingkat bawah yaitu, desa/kelurahan. Hal ini juga ditemukan di Desa Ketapangkuning, pemerintah desa telah memberikan himbauan untuk selalu mematuhi protokol kesehatan yang ada. Mulai dari penggunaan masker, penjagaan jarak, dan peningkatan kebersihan diri. Tindakan tersebut dilakukan sebagai upaya dalam penekanan kasus virus corona. 
Namun, jika dilihat dari sudut pandang sosial-budaya dan keagamaan, suatu masyarakat tentu memiliki cara tersendiri dalam mengatasi suatu masalah sosial, salah satunya yaitu melalui tradisi. Tradisi ialah pola perilaku atau kepercayaan yang telah menjadi bagian dari suatu budaya yang telah lama dikenal, sehingga menjadi adat istiadat dan kepercayaan secara turun temurun. Dalam ilmu antropologi, tradisi lahir dari akal manusia yang dapat memperkirakan kondisi dirinya dan sekitar. Sehingga, dapat mengadakan pilihan dan seleksi dari berbagai alternatif yang ada untuk mencapai efektifitas yang optimal dalam mempertahankan hidupnya (Koentjaraningrat, 2009).

Suatu tradisi tidak hanya dijalankan secara kultural saja, tetapi juga dalam sisi keagamaan. Keberadaan agama dalam masyarakat telah melekat hampir di seluruh bidang, termasuk budaya. Tradisi keagamaan telah menjadi elemen penting dalam sebagian besar masyarakat. Akan tetapi, keberadaan pandemi telah menimbulkan berbagai problema dalam masyarakat. Pembatasan kegiatan hingga pelarangan pelaksanaan tradisi agama memperoleh banyak tanggapan.

Pada lingkungan masyarakat tertentu, tradisi masih banyak dijalankan dalam menghadapi pandemi ini, salah satunya yaitu melalui Tradisi Yasinan. Meskipun pada masa pandemi, kegiatan ini tetap dilangsungkan dengan tetap mematuhi protokol kesehatan yang ada. Kegiatan ini menjadi momentum untuk mengirimkan do'a kepada leluhur dan juga sebagai bentuk pengharapan agar senantiasa diberikan kesehatan dan keselamatan. Tradisi Yasinan merupakan salah satu wujud menyatunya nilai-nilai keagamaan dalam kehidupan sosial bermasyarakat. Tradisi ini selain difungsikan sebagai media yang menghubungkan pada 
Tuhan (habluminallah), juga menjadi penghubung antar manusia (habluminannas).

Tradisi Yasinan menjadi kegiatan rutin yang dilakukan oleh masyarakat Desa Ketapangkuning. Tradisi yang didirikan oleh kelompok perempuan setempat dilaksanakan setiap malam Jum'at. Tradisi ini menjadi kegiatan rutin mingguan yang dilakukan di rumah-rumah warga. Kegiatan Yasinan juga menjadi tradisi turun menurun. Hal ini ditunjukkan dengan proses regenerasi yang melibatkanibu-ibu usia muda. Jika dilihat dari keanggotaan, anggota Yasinan terdiri dari ibu-ibu usia muda (20 sampai 30 tahun) hingga tua (30 sampai 70 tahun).

Proses pelaksanaan kegiatan ini tidak berbeda jauh dengan yang dilakukan di daerah lain. Kegiatan ini dipandu oleh salah satu pengurus, dan dimulai dengan muqodimah (pembukaan). Kemudian, dilanjutkan dengan pembacaan Surah Yasin, Tahlil, shalawat, dan do'a secara bersamasama. Akan tetapi, terdapat hal yang menarik dalam pelaksanaan Tradisi Yasinan di Desa Ketapangkuning. Dalam kegiatan ini terdapat praktik menabung yang disusun seperti mekanisme arisan. Menurut Putri (2018), Arisan telah menjadi budaya di masyarakat. Kegiatan ini dapat dilakukan oleh berbagai kelompok, mulai dari kelompok PKK hingga kelompok dagang. Arisan tersebut dapat dilakukan dalam kurun waktu tertentu, mulai dari setiap minggu, bulan, hingga tahun. Setiap anggota yang terlibat dalam kegiatan ini, akan dilakukan penarikan sejumlah uang. Uang hasil penarikan tersebut, selanjutnya akan diberikan kepada yang memperoleh giliran. Konsep arisan tersebut, juga dilaksanakan dalam kegiatan Yasinan yang ada di Desa Ketapangkuning.

\section{Sistem 'Arisan Islami'}


Anggota yang terlibat dalam kegiatan 'Arisan Islami' merupakan anggota aktif dari kelompok Yasinan tersebut. Setiap anggota yang terlibat dapat menabung sejumlah uang kepada bendahara atau pengurus Yasinan. Besaran uang yang diberikan tergantung kemampuan setiap anggota. Berdasarkan hasil pengamatan serta wawancara yang dilakukan, rata-rata anggota Yasinan memberikan uang dengan jumlah minimal Rp 10.000 dan maksimal Rp 100.000. Uang tersebut akan diberikan kepada anggota yang memperoleh arisan pada pertemuan sebelumnya. Bagi anggota yang memperoleh uang tersebut, selanjutnya akan dilakukan pencatatan dan berkewajiban untuk membayar dengan sejumlah uang yang sama kepada anggota tersebut.

Seperti dalam kegiatan arisan pada umumnya, pada setiap akhir acara akan dilakukan undian. Sistem undian tersebut digunakan untuk menentukan giliran anggota selanjutnya yang memperoleh arisan tersebut. Anggota yang terpilih akan mendapatkan uang hasil tabungannya dan tabungan anggota lain, sekaligus menjadi tuan rumah dalam kegiatan Yasinan berikutnya. Kegiatan akhir ini menjadi hal yang paling ditunggu bagi anggota Yasinan yang mengharapkan gilirannya. Praktik 'arisan islami' ini tidak diwajibkan bagi seluruh anggota yang terlibat. Nominal tabungan yang dibayarkan juga dapat menyesuaikan kondisi keuangan tiap-tiap anggota. Sehingga, besaran uang yang dibayarkan dan diterima oleh setiap anggota menjadi berbeda-beda, sesuai dengan yang ditabungkan.

Akibatnya, terdapat perubahan keterlibatan anggota secara langsung dalam kegiatan Yasinan yang digelar setiap hari Kamis ini. Umumnya, anggota yang telah memperoleh arisan menjadi jarang mengikuti kegiatan Yasinan secara langsung. Anggota usia muda lebih 
sedikit mengikutsertakan diri dalam pelaksanaan Yasinan. Berdasarkan wawancara yang dilakukan, kelompok ini tidak ingin memperoleh giliran atau mendapatkan arisan tersebut. Hal ini disebabkan karena Yasinan dijadikan sebagai tempat untuk menabung. Sehingga, memperoleh giliran diakhir sama dengan memperoleh tabungan selama periode Yasinan tersebut. Selain itu, anggota yang tidak dapat memberikan sejumlah uang dalam kegiatan Yasinan ini, akan memilih untuk tidak ikut terlibat langsung dalam pelaksanaan Yasinan. Praktik ini secara tidak langsungmenunjukkan adanya pergeseran nilai-nilai Tradisi Yasinan pada masyarakat Desa ketapangkuning.

Adanya praktik 'arisan islami' ini telah mempengaruhi konstruksi sosial yang berbeda mengenai tradisi Yasinan. Tradisi tersebut tidak hanya menjadi suatu rutinitas keagamaan, melainkan juga sebagai pembentuk identitas sosial di masyarakat. Perbedaan besaran uang yang diberikan oleh setiap anggota Yasinan telah membentuk identitas tersendiri. Anggota yang menabung dengan kisaran Rp 50.000-Rp 100.000 termasuk dalam kelompok menengah atas. Sedangkan, anggota yang menabung dengan kisaran Rp 10.000 - Rp 50.000 termasuk dalam kelompok menengah bawah.

\section{Konstruksi Sosial Tradisi Yasinan dalam Masyarakat}

Menurut Berger dan Luckman (1990), konstruksi sosial adalah proses dimana seseorang berinteraksi dan membentuk realitas-realitas. Teori ini lebih menekankan pada makna serta penafsiran yang dikonstruksi secara bersama dalam jaringan masyarakat(Adhi Dharma, 2018). Konstruksi tersebut selanjutnya berimplikasi pada kehidupan organisasi, seperti aturan, nilai, dan perbuatan yang diterima dalam organisasi tersebut. Konstruksi sosial atas realitas sehari-hari dipengaruhi oleh cara 
setiap individu dalam memahami sesuatu berdasarkan kebiasaan dan cadangan pengetahuannya. Pada konsep ini, Berger membagi masyarakat ke dalam dua jenis yaitu, masyarakat sebagai realitas objektif dan masyarakat sebagai realitas subjektif.

Masyarakat sebagai kenyataan objektif (objective reality) dapat dipahami melalui unsur institusionalisasi dan legitimasi (Karman, 2015). Proses institusionalisasi (pelembagaan) diawali dengan eksternalisasi yang dilakukan berulang-ulang. Eksternalisasi ditunjukkan melalui pengungkapan subjektivitas diri melalui serangkaian kegiatan yang dilakukan secara terus-menerus. Eksternalisasi dalam hal ini yaitu keberadaan Tradisi Yasinan sebagai kegiatan rutin di masyarakat. Pada awalnya tradisi ini merupakan bagian dari syiar agama Islam yang disampaikan oleh Sunan Kalijaga terutama di wilayah Jawa. Tradisi Yasinan sebagai wujud akulturasi antara agama pribumi dan agama Islam. Agama Islam yang bersifat dinamis menjadi sangat mudah untuk memasuki setiap elemen masyarakat. Hingga kini tradisi Yasinan masih terus dijalankan dan menjadi bagian dari realitas sosial.

Kegiatan Yasinan yang dilakukan secara rutin telah melahirkan pola yang dipahami secara kolektif, dan menghasilkan pembiasaan (habitualisasi) (Samuel, 2012). Pembiasaan ini ditunjukkan dengan terjadwalnya kegiatan Yasinan setiap malam Jum'at. Aktivitas yang dilakukan oleh aktor maupun pelaku dalam kegiatan Yasinan tersebut mengalami tipifikasi. Tipifikasi ini dapat diamati dalam kegiatan Yasinan diwariskan dari generasi ke generasi. Proses pentradisian pengalaman dan pewarisan pengalaman tersebut, melahirkan peranan sebagai wujud dari keseluruhan rangkaian perilaku yang melembaga. Sistem pewarisan ini dapat dilihat dari keberlanjutan Tradisi Yasinan di masyarakat. Anggota 
Yasinan yang tidak hanya melibatkan ibu-ibu usia tua, melainkan juga ibuibu usia muda. Proses regenerasi itupun terus berlanjut dan disadari atas kesadaran diri masing-masing. Hampir seluruh perempuan yang telah berkeluarga akan secara otomatis melibatkan diri dalam kegiatan Yasinan.

Habitualisasi dan tipifikasi yang dialami secara kolektif akan berpotensi melahirkan suatu pranata sosial. Suatu tradisi dapat dikatakan sebagai pranata sosial, jika telah menjadi sesuatu yang umum, eksternal (objektif), dan koersif. Sifat umum dari Tradisi Yasinan ditunjukkan melalui keterlibatan seluruh perempuan dari beragam kelas atau status di masyarakat. Sedangkan, eksternal (objektif) ditunjukkan melalui kesadaran masyarakat, khususnya kelompok perempuan untuk terlibat dalam kegiatan Yasinan. Terakhir, koersif (paksaan) secara tidak langsung ditunjukkan melalui proses regenerasi yang terjadi. Hampir seluruh kelompok perempuan telah terlibat dalam kegiatan Yasinan tersebut.

Lebih lanjut, legitimasi merupakan proses obyektivasi pengetahuan secara sosial untuk membenarkan tatanan yang ada. Pada legitimasi ini tidak dapat dipisahkan dari proses pemahaman terhadap pengetahuan agama. Dalam agama Islam, kegiatan membaca Surah Yasin, Tahlil, Sholawat, dan do'a merupakan bagian dari ibadah. Selain dipahami sebagai bagian ibadah, kegiatan Yasinan juga dimanfaatkan untuk mengirim do'a kepada leluhur. Pemilihan hari pelaksanaan di malam Jum'at, juga tidak lepas dari pengetahuan yang dibawah oleh masyarakat. Hari Jum'at dalam pandangan orang Islam dipercaya sebagai hari baik, sehingga banyak amalan ibadah yang dilakukan pada hari tersebut. Proses pemahaman inilah yang kemudian menjadi acuan bagi masyarakat untuk tetap menjalankan Tradisi Yasinan. 
Selain itu, Berger juga memandang masyarakat sebagai realitas subjektif melalui konsep internalisasi, eksternalisasi, dan objektivasi (Ritzer \& Godman, 2016). Internalisasi adalah proses penerimaan definisi situasi yang telah terlembaga. Trdisi Yasinan dapat disama artikan dengan kegiatan mengaji yang dilakukan secara bersama-sama. Proses internalisasi tradisi ini telah dilakukan sejak kecil melalui kegiatan mengaji di Taman Pembelajaran Al-Qur'an (TPA/TPQ). Kemudian pada usia remaja, anakanak akan diarahkan untuk mengikuti kegiatan rutinan yaitu pembacaanDiba' (shalawat nabi). Setelah berkeluarga, maka akan diarahkan dalam kegiatan Yasinan. Pada proses internalisasi setiap individu akan mendapatkan sosialisasi, baik primer maupun sekunder. Sosialisasi primer dapat dilakukan oleh orang tua kepada anak, sedangkan sekunder melalui lingkungan sekitar. Seperti, teman, masyarakat, atau lembaga-lembaga terkait.

Pada kegiatan di TPA/TPQ dan juga Diba' (shalawat nabi), praktik menabung juga turut disosialisasikan. Namun, terdapat perbedaan antara kegiatan menabung di TPA/TPQ, Diba', dan Yasinan. Kegiatan menabung di TPA/TPQ tidak terdapat praktik Arisan. Proses pengambilan uang dilakukan setiap bulan ramadhan tiba, atau dapat diambil sewaktu-waktu. Tujuan dari menabung tersebut untuk membentuk kebiasaan pada anak. Sedangkan, dalam kegiatan $D i b a^{\prime}$, praktik menabung dilakukan dengan konsep membayar iuran anggota sebesar Rp 5.000. Pada akhir kegiatan pembacaan $D i b a^{\prime}$ akan dilakukan pengundian untuk menentukan giliran sebagai tuan rumah. Selanjutnya, uang hasil iuran akan diserahkan kepada anggota yang terpilih dalam undian. Uang iuran tersebut dimanfaatkan untuk membeli konsumsi selama berlangsungnya kegiatan Diba'. Berdasarkan dua aktivitas tersebut secara tidak langsung telah 
menginternalisasikan konsep menabung dalam kegiatan-kegiatan islami kepada anak-anak. Sehingga, secara tidak langsung praktik menabung atau 'Arisan Islami' terus berlanjut dari generasi ke generasi.

Proses ini kemudian dilanjutkan dengan eksternalisasi, yaitu ekspresi individu dalam realitas kehidupan (Sulaiman, 2016). Setelah proses penanaman nilai-nilai telah dilakukan, maka setiap individu dapat menerapkannya secara langsung di masyarakat. Eksternalisasi ini ditunjukkan dengan keterlibatan individu dalam kegiatan Yasinan. Pada masyarakat Desa Ketapangkuning, wujud keikutsertaan dalam kegiatan Yasinan menjadi berbeda-beda. Berdasarkan hasil wawancara yang telah dilakukan, menunjukkan sikap yang beragam antara anggota muda dan tua.

Pada anggota tua, kegiatan Yasinan dimanfaatkan sebagai media untuk mendekatkan diri pada sang pencipta. Kelompok tua lebih dipercaya sebagai pengurus kegiatan Yasinan ini, misalnya menjadi penanggung jawab, bendahara, dan posisi utama lainnya. Praktik 'arisan islami' menjadi hal yang tidak begitu penting bagi kelompok ini. Namun, jumlah kelompok tua menjadi sangat sedikit, jika dibandingkan dengan kelompok muda. Bagi kelompok muda, kegiatan Yasinan lebih didominasi dengan tujuan menabung. Sehingga, sebagian besar kelompok ini memilih ikut acara Yasinan di akhir agar hasil tabungan dapat diperoleh secara penuh. Jika tidak demikian, keikutsertaan dalam pelaksanaan Yasinan ditujukan untuk memperoleh giliran undian. Dengan demikian, maka uang hasil tabungan sendiri dan anggota lain dapat dipergunakan untuk keperluan sehari-hari.

Proses Eksternalisasi ini tidak dapat dipisahkan dari adanya objektivasi, yakni hasil aktivitas manusia yang ditransmisikan dan dibagikan kepada orang lain. Bentuk dari objektivasi ini dapat berupa 
penggunaan bahasa dan simbol yang sama secara terus menerus. Objektivasi dari praktik 'arisan islami' yang ada dalam tradisi Yasinan ditunjukkan melalui pemberian amplop berisi uang yang diberikan kepada anggota yang memperoleh undian. Amplop tersebut akan ditukar dengan makanan berupa mie dan air, sebagai tanda terima uang tabungan. Uang tersebut kemudian akan dicatat di buku, yang kemudian akan dikembalikan saat anggota yang lain mendapat giliran. Sehingga, peyebutan nama hasil undian menjadi hal yang di tunggu-tunggu dari kegiatan Yasinan tersebut.

Selain itu, besaran uang yang diberikan menjadi tolak ukur tersendiri dalam masyarakat. Anggota yang menabung dengan kisaran Rp 50.000 - Rp 100.000 dikonstruksi sebagai masyarakat kelas menengah atas. Umumnya, anggota yang menabung dengan jumlah tersebut merupakan masyarakat yang mampu secara ekonomi dan juga termasuk kerabat dekat. Bagi kerabat dekat, menabung dengan jumlah besar tersebut dilandasi oleh rasa kepercayaan. Pada masyarakat menengah atas pun akan mempertimbangkan untuk menentukan jumlah uang yang ditabungkan. Jika, anggota yang memperoleh giliran dianggap sebagai kelompok menengah bawah. Maka, besaran uang yang diberikan juga tidak akan banyak. Hal ini dikhawatirkan ketidakmampuan kelompok tersebut untuk membayar gantinya.

Setelah mengalami ekternalisasi, selanjutnya terjadi proses objektivasi. Pada tahap ini, hasil aktivitas yang dilakukan manusia akan ditransmisikan atau disebar kepada orang lain. Awalnya, Tradisi Yasinan disebar atau diperkenalkan secara turun temurun sebagai kegiatan rutin umat Islam. Namun, seiring berkembangnya zaman kegiatan ini telah mengalami pergeseran. Konsep Yasinan lebih ditekankan pada sistem 
'Arisan Islami' yang ditujukan sebagai kegiatan menabung. Beberapa anggota muda beralasan bahwa keterlibatan pada aktivitas Yasinan didorong oleh keinginan menabung. Hal ini disebabkan, dalam proses 'Arisan Islami' lebih menjanjikan hasilnya. Jika terdapat anggota yang tidak membayar ganti uang tabungan anggota lain akan memperoleh stereotip yang buruk dari masyarakat. Selain itu, dalam kegiatan 'Arisan Islami tidak terdapat bunga. Sehingga, uang yang diperoleh dapat diterima secara utuh. Dalam kegiatan Yasinan konsep bunga dinamakan dengan pembayaran kas. Kas diperoleh melalui iuran tiap anggota yang diinisiasi oleh RT (Rukun Tetangga) masing-masing. Anggota Yasinan yang aktif setiap menjelang kegiatan Yasinan diwajibkan membayar kas sebesar Rp 4.000.

Proses Internalisasi, Eksternalisasi, dan Objektivasi terjadi secara dialektis antara individu dengan budaya sosial (social cultural). Sehingga, kerangka yang ditawarkan oleh Berger tidak dapat dipisahkan dari makna yang melekat pada aktor dalam gejala sosial. Proses internalisasi menjadi ujung tombak dalam menanamkan makna pada diri individu. Proses yang didapat melalui kegiatan sosialisasi ini menjadi penentu berlangsungnya konstruksi sosial. Setelah mengalami proses internalisasi tersebut, individu akan mengimplementasikan secara langsung dalam aktivitas sehari-hari. Terakhir, hasil aktivitas tersebut akan dibagikan kepada orang lain sebagai bagian dari objektivasi.

\section{SIMPULAN}

Berdasarkan hasil penelitian yang dilakukan menunjukkan bahwa, Tradisi Yasinan di konstruksi secara berbeda oleh masyarakat. Tradisi Yasinan bagi masyarakat Desa Ketapangkuning tidak hanya sebagai suatu 
ritual keagamaan yang dilakukan secara rutin, melainkan juga sebagai media pembentukan identitas sosial. Identitas tersebut terbentuk melalui praktik 'arisan islami'. Praktik ini dijalankan seperti kegiatan arisan pada umumnya, terdapat kegiatan menabung dan proses pengundian. Praktik ini telah menjadi bagian dari Tradisi Yasinan yang juga mengalami proses regenerasi. Akan tetapi, keberadaan praktik 'arisan islami' telah mengubah esensi kegiatan Yasinan yang sebenarnya. Hal ini disebabkan karena pemahaman yang berbeda antar anggota terkait pelaksanaan Tradisi Yasinan tersebut.

Pergeseran konstruksi sosial Tradisi Yasinan dapat dipahami melalui konsep internalisasi, ekternalisasi, dan objektivasi. Internalisasi merupakan proses penanaman makna kepada individu. Hal ini ditunjukkan dalam keterlibatan anak-anak dalam kegiatan islami yang juga melakukan praktik menabung atau 'Arisan Islami'. Sedangkat, pada eksternalisasi ditunjukkan melalui keterlibatan atau proses regenerasi dalam pelaksanaan Yasinan. Terakhir, objektivasi yang ditunjukkan melalui penyebaran Tradisi Yasinan dalam masyarakat melalui konsep 'Arisan Islami'. Melalui ketiga konsep tersebut dapat dipahami bahwa terjadi pergeseran nilai dalam Tradisi Yasinan pada masyarakat Desa Ketapangkuning.

Kajian ini hanya memfokuskan pada Tradisi Yasinan yang diadakan pada masyarakat pedesaan, khususnya di Desa Ketapangkuning. Penulis menitikberatkan pembahasan pada praktik 'Arisan Islami' yang terjadi dalam kegiatan Yasinan. Berdasarkan temuan tersebut, penulis berharap dapat dilakukan tinjau ulang pada pelaksanaan Tradisi Yasinan dalam lingkup lain, seperti pesantren. 


\section{REFERENCES}

(1) Adhi Dharma, F. (2018, September 1). The Social Construction of Reality: Peter L. Berger's Thoughts About Social Reality.Jurnal Ilmu Komunikasi, 7(1), 1-9.

(2) Berger, Peter \& Thomas Luckman. (1990). Tafsir Sosial atas Kenyataan Risalah tentang Sosiologi Pengetahuan. Jakarta: LP3S.

(3) STRATEGI DAKWAH NU DALAM MEMBANGUN MENTAL DAN KARAKTER MASYARAKAT. Jurnal Walisongo,22(2), 297-320.

(4) Karman. (2015, March 2). Konstruksi Realitas Sosial Sebagai Gerakan Pemikiran (Sebuah Telaah Teoretis Terhadap Konstruksi Realitas Peter L. Berger). Penelitian Dan Pengembangan Komunikasi Dan Informatika, 5(3), 11-23.

(5) Koentjaraningrat. (2009). Pengantar Ilmu Antropologi (2009th ed.). Jakarta: Rineka Cipta.

(6) Muniri, A. (2020, June 24). TRADISI SLAMETAN: YASINAN MANIFESTASI NILAI SOSIAL-KEAGAMAAN DI TRENGGALEKstasi Nilai Sosial-Keagamaan di Trenggalek. J-PIPS (Jurnal Pendidikan Ilmu Pengetahuan Sosial), 6(2), 71.

(7) Puti, R. A., \& Suryaningsih, S.. A. (2018). Analisis Kegiatan Arisan dalam Perspektif Islam di Kelurahan Sememi Surabaya. Jurnal Ekonomi Islam, 1(2), 55-67.

(8) Ritzer, G., \& Godman, D. J. (2016). Teori Sosiologi.Yogyakarta: Kreasi Wacana.

(9) Roiawan, A. (2019). Tradisi Pembacaan Yasin (Studi Living Qur'an Di Pondok Pesantren Kedung Kenong Madiun).(Skripsi). Institut Agama Islam Negeri (IAIN) Ponorogo.

(10) Samuel, Hanneman. (2012). Peter L. Berger Sebuah Pengantar Ringkas. Depok: Kepik

(11) Sugiyono. (2012). Metode Penelitian Kuantitatif Kualitatif dan R\&D. Bandung: Alfabeta.

(12) Sulaiman, A. (2016, June 1). Memahami Teori Konstruksi Sosial Peter L. Berger. Jurnal Society, 4(1), 15-22.

(13) Sumarni. (2018, January 19). Persepsi masyarakat islam terhadap tradisi yasinan pada malam jumat (studi kasus pondok pesantren annahdlah). (Skripsi). Universitas Hasanuddin.

(14) Zainuddin, A., \& Hikmah, F. (2019, Mei 5). Tradisi Yasinan (Kajian Living Qur'an Di Ponpes Ngalah Pasuruan). Mafhum, 4(1), 9-26. 